\title{
A case of nasal myiasis due to Oestrus ovis (Diptera: Oestridae) in a llama (Lama glama)
}

\author{
Um caso de miíase nasal devido a Oestrus ovis (Diptera: Oestridae) em lhama (Lama glama) \\ Luis Antonio Gomez-Puerta ${ }^{1 *}$; Karen Ann Alroy²; Daniel Santiago Ticona ${ }^{3}$; \\ Maria Teresa Lopez-Urbina ${ }^{1}$; Armando Emiliano Gonzalez ${ }^{1}$
}

${ }^{1}$ School of Veterinary Medicine, Universidad Nacional Mayor de San Marcos - UNMSM, Lima, Peru

${ }^{2}$ Tufts Cummings School of Veterinary Medicine, North Grafton, MA, USA

${ }^{3}$ Department of Animal Health, Inversiones Veterinarias S. A., Lima, Peru

Received May 8, 2013

Accepted June 24, 2013

\begin{abstract}
Infection by the larval form of Oestrus ovis (sheep bot fly) is common in many areas of Peru. This is an obligate parasite of sheep and goats, and it is the cause of oestrosis, or nasal myiasis, which can lead to severe clinical manifestations in livestock. A case of myiasis caused by O. ovis in a llama (Lama glama) in Cuzco, Peru, is reported here. This llama presented with respiratory distress and died due to bilateral hemorrhagic pneumonia. During the necropsy, six intact dipterous larvae were recovered from the nasal fossae and cranial sinuses being identified as $O$. ovis. This is the first report of nasal myiasis in llamas due to O. ovis in Peru.
\end{abstract}

Keywords: Oestrus ovis, myiasis, llama, Lama glama.

\section{Resumo}

Infecção pela forma larval de Oestrus ovis (bicho da cabeça) é comum em muitas regiōes do Peru. Este é um parasito obrigatório de ovinos e caprinos, e é a causa de oestrose ou miíase nasal, que pode conduzir à manifestaçôes clínicas graves nos animais. Relatou-se um caso de miíase causada por O. ovis numa lhama (Lama glama) em Cuzco, Peru. A lhama apresentou insuficiência respiratória e morreu de pneumonia bilateral hemorrágica. Durante a necropsia, seis larvas intactas do díptero foram recuperadas das fossas nasais e dos seios cranianos e identificadas como O. ovis. Este é o primeiro relato de míase nasal em lhamas por O. ovis no Peru.

Palavras-chave: Oestrus ovis, myiasis, lhama, Lama glama.

Myiasis is defined as the invasion of organs and tissues of humans or vertebrates by dipterous larvae, which then feed upon the living or dead tissues for some period of time (HALL; WALL, 1995). Oestrus ovis Linnaeus, 1758, or the sheep bot fly, deposits its first instar in or near the nasal passages of small ruminants, and the larvae subsequently develop within the nasal fossae and cranial sinuses (HEATH; JOHNSTON, 2001). The pathogenicity of $O$. ovis is believed to be the result of mechanical trauma induced by larval hooks and spines (DORCHIES et al., 2006). The clinical manifestations of oestrosis may include long-lasting rhinitis and sinusitis, or the symptoms may have a clear-cut seasonal pattern (MARTINEZ et al., 1999).

In Peru, $O$. ovis is a common parasite among sheep and goats (ZALDIVAR, 1991). While it is believed that three species of bot

*Corresponding author: Luis Antonio Gomez-Puerta

Laboratorio de Medicina Veterinaria Preventiva, School of Veterinary

Medicine, Universidad Nacional Mayor de San Marcos - UNMSM,

Av. Circunvalacion, 2800, San Borja, Lima 41, Peru

e-mail: lucho92@yahoo.com fly can parasitize the nasal passages and sinuses of South American camelids (SACs), there is still a lack of information regarding the life cycle of $O$. ovis in these camelid species, given that no case reports on O. ovis in SACs exist in the literature (FOWLER, 1998). The only published report of a bot fly in a SAC was a case of a nasopharyngeal bot-fly of deer (Cephenymia sp.) that was found in a dyspneic 9-month-old llama in Oregon, USA (MATTOON et al., 1997). Here, we present a case of nasal myiasis in a llama (Lama glama) in Cuzco, Peru, caused by the parasite $O$. ovis.

A 1.8-year-old, $70 \mathrm{~kg}$ male llama that was living at the experimental station of the IVITA Veterinary Center, University San Marcos, in Marangani, Cuzco, Peru, began to develop respiratory symptoms. This llama belonged to a mixed herd of free-roaming sheep, llamas and alpacas from the Abra La Raya locality in Cuzco. This region has a cold climate, and is situated at approximately $3,700 \mathrm{~m}$ above sea level. The llama was sent to the clinic because it presented dyspnea, respiratory stridor, and bilateral mucous nasal discharge. Pneumonia was diagnosed, and 
the animal was treated with an antibiotic (oxytetracycline, $5 \mathrm{mg} / \mathrm{kg}$ intramuscularly) and anti-inflammatory therapy (dexamethasone, $0.05 \mathrm{mg} / \mathrm{kg}$ intramuscularly). However, the clinical signs lingered on and, four months later, the animal died suddenly.

At necropsy, the lungs revealed pulmonary hemorrhage and the cause of death was determined to be bilateral hemorrhagic pneumonia. Upon further inspection of the upper respiratory system, six intact dipterous larvae were discovered within both the nasal fossae and the cranial sinuses (Figure 1). All of the larvae were collected from the nasal cavity. Microscopic examination of the cephalopharyngeal skeleton and posterior spiracular plate was performed using the keys of Papavero (1977) and Colwell (2006), and these larvae were confirmed to be $O$. ovis.

One larva was identified as a second-instar larva (L-II) and the other five larvae were identified as third-instar larvae (L-III). The second-instar larva was $1.6 \mathrm{~cm}$ long and $0.6 \mathrm{~cm}$ in diameter. The third-instar larvae had the following characteristics: cream color, $2.3-2.8 \mathrm{~cm}$ in length and $0.6-0.8 \mathrm{~cm}$ in diameter.

This case suggests that llamas are able to serve as accidental hosts for the $O$. ovis species of bot fly. The $O$. ovis larvae in this llama were able to complete their life stage development up to the third and final instar larval stage. This llama's clinical history of persistent pneumonia probably contributed towards establishing a state of relative immunosuppression. It is likely that these parasitic larvae were able to develop in the llama because of its compromised immunological state. Moreover, the llama lived in a mixed herd with sheep and had the opportunity of exposure from a definitive host. The clinical signs observed in this llama were similar to those experienced by sheep infested with $O$. ovis.

The sheep bot fly, O. ovis, is one of the most ubiquitous parasites of both the Old and the New World (HALL; WALL, 1995). These flies can thrive in a wide range of environmental temperatures, and despite their specificity as parasites of sheep and goats, $O$. ovis has been reported in a variety of hosts (BIGGS et al., 1998). Many reports have provided prevalence data for various regions, including both temperate and tropical areas (ABO-SHEHADA et al., 2000; CARACAPPA et al., 2000; DORCHIES et al., 2000). In hot and dry climates, the nasal discharge caused by oestrosis

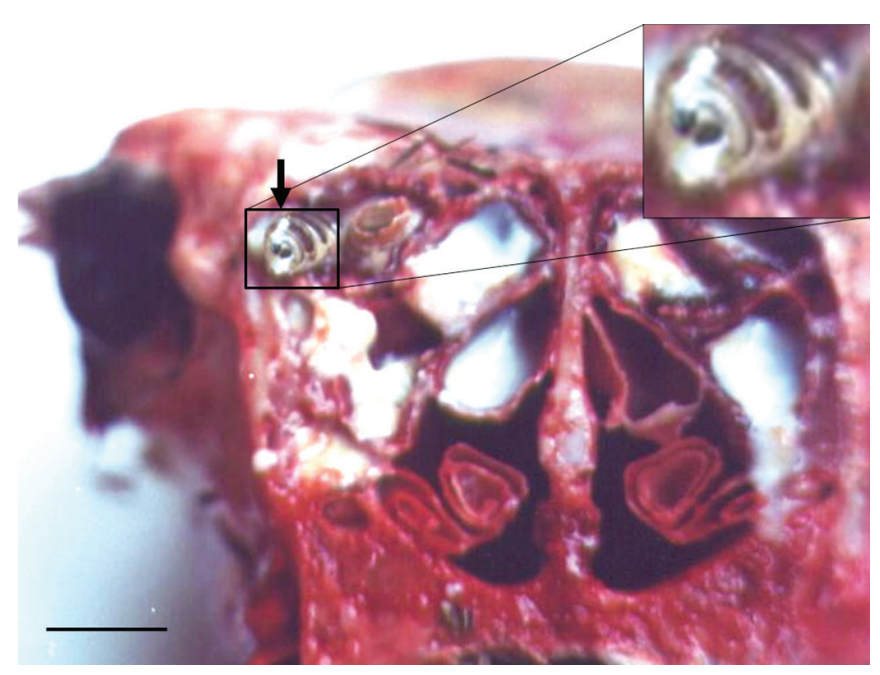

Figure 1. Oestrus ovis in the cranial sinuses (in situ). Scale-bar: $2.00 \mathrm{~cm}$. can become caked with dust, making breathing very difficult (DORCHIES et al., 2006).

Oestrosis is an important disease that has implications for communities' economies and for animal and human health (CARACAPPA et al., 2000; DORCHIES et al., 2000; COLWELL et al., 2006). The magnitude of the clinical presentation of the disease is directly correlated with the number of larvae deposited. Light infestations in sheep comprising 15 or less larvae can, in fact, be well tolerated by the animal (COLWELL et al., 2006). However, heavy infestations can have serious consequences, resulting in losses of meat, wool and milk production (DORCHIES et al., 2003).

Although $O$. ovis is a common parasite in sheep and goats in areas around the globe, $O$. ovis has the potential to infest other types of ruminants. In Egypt, Old World camels can be infested with O. ovis (FEKRY et al., 1997; MORSY et al., 1991). This fly also has been reported in wild sheep and goats, including the Siberian ibex (Capra ibex sibirica), argali (Ovis ammon), bighorn sheep (O. canadensis), Barbary sheep (Ammotragus lervia) and the European mouflon (O. orientalis musimon) (MORENO et al., 1999).

In the present study, one llama was infected with $O$. ovis. This report documents the first known case of nasal myiasis in a llama by $O$. ovis in Peru.

\section{Acknowledgments}

Luis Gomez-Puerta is supported by a training grant Fogarty/ $\mathrm{NIH}$ (grants D43TW008273) and by the International Foundation for Science (IFS grant B/5225-1). Karen Alroy is a scholar in the Fogarty/NIH International Clinical Research Scholars Program at Vanderbilt University (R24 TW007988).

\section{References}

Abo-Shehada MN, Arab B, Mekbel R, Williams D, Torgerson PR. Age and seasonal variations in the prevalence of Oestrus ovis larvae among sheep in northern Jordan. Prev Vet Med 2000; 47(3): 205-212. http:// dx.doi.org/10.1016/S0167-5877(00)00160-4

Biggs HC, McClain E, Muller GL, Anthonissen M, Hare KM. A prediction model for strike in the sheep nasal fly, Oestrus ovis, in Namibia. Prev Vet Med 1998; 33(1-4): 267-282. http://dx.doi.org/10.1016/S01675877(97)00015-9

Caracappa S, Rilli S, Zanghi P, Di Marco V, Dorchies P. Epidemiology of ovine oestrosis (Oestrus ovis Linné 1761, Diptera: Oestridae) in Sicily. Vet Parasitol 2000; 92(3): 233-237. http://dx.doi.org/10.1016/S03044017(00)00317-4

Colwell DD. Larval morphology. In: Colwell DD, Hall MJ, Scholl PJ. The Oestrid flies: Biology, host - parasite, relationships, impact and management. Cambridge: CABI Publishing; 2006. p. 98-123. http:// dx.doi.org/10.1079/9780851996844.0098

Colwell DD, Hall MJ, Scholl PJ. A synopsis of the biology, hosts, distribution, disease significance and management of the genera. In: Colwell DD, Hall MJ, Scholl PJ. The Oestrid flies: Biology, host - parasite, relationships, impact and management. Cambridge: CABI Publishing; 2006. p. 220-305. http://dx.doi. org/10.1079/9780851996844.0220 
Dorchies P, Bergeaud JP, Tabouret G, Duranton C, Prevot F, Jacquiet P. Prevalence and larval burden of Oestrus ovis (Linne 1761) in sheep and goats in northern mediterranean region of France. Vet Parasitol 2000; 88(3-4): 269-273. http://dx.doi.org/10.1016/S03044017(99)00215-0

Dorchies P, Wahetra S, Lepetitcolin E, Prevot F, Grisez C, Bergeaud JP, et al. The relationship between nasal myiasis and the prevalence of enzootic nasal tumours and the effects of treatment of Oestrus ovis and milk production in dairy ewes of Roquefort cheese area. Vet Parasitol 2003; 113(2): 169-174. http://dx.doi.org/10.1016/S03044017(03)00032-3

Dorchies PH, Tabouret G, Hoste H, Jacquiet P. Larval-host parasite relationships. Part D: Oestrinae host-parasite interactions. In: Colwell DD, Hall MJ, Scholl PJ. The Oestrid flies: Biology, host - parasite, relationships, impact and management. Cambridge: CABI Publishing; 2006. p. 191-200.

Fekry AA, El Serougi AO, Ayoub SA. Oestrus ovis (sheep nasal fly) infesting the eyes and the nose of a camel keeper family. J Egypt Soc Parasitol 1997; 27(2): 493-496. PMid:9257988.

Fowler M. Medicine and surgery of South American camelids: llama, alpaca, vicuña, guanaco. Hoboken: Wiley-Blackwell Press; 1998.

Hall M, Wall R. Myiasis of humans and domestic animals. Adv Parasitol 1995; 35: 257-334. http://dx.doi.org/10.1016/S0065308X(08)60073-1
Heath AC, Johnston C. Nasal myiasis in a dog due to Oestrus ovis (Diptera: Oestridae). $N Z$ Vet J 2001; 49(4): 164. PMid:16032186. http://dx.doi.org/10.1080/00480169.2001.36226

Martinez S, Moreno T, Becerra C. Estrosis. In: Cordero del Campillo M, Rojo Vazquez FD. Parasitología Veterinaria. Spain: Mc-Graw Hill Interamericana; 1999. p. 395-9.

Mattoon JS, Gerros TC, Parker JE, Carter CA, LaMarche RM. Upper airway obstruction in a llama caused by aberrant nasopharyngeal bots (Cephenemyia sp.). Vet Radiol Ultrasound 1997; 38(5): 384386. PMid:9335098. http://dx.doi.org/10.1111/j.1740-8261.1997. tb02103.x

Moreno V, Pérez JM, Moreno PA, Granados JE, Ruiz-Martinez I, Soriguer RC, et al. Oestrid myiasis in European mouflon from Spain. J Wildl Dis 1999; 35(1): 78-81. PMid:10073350.

Morsy TA, Fayad ME, Salama MM, Sabry AH, El Serougi AO, Abdallah KF. Some myiasis producers in Cairo and Giza abattoirs. J Egypt Soc Parasitol 1991; 21 (2): 539-546. PMid:1875078.

Papavero N. The world Oestridae (Diptera), mammals and continental drift. Springer Netherlands; 1977.

Zaldivar S. Zooparásitos de interés veterinario en el Perú. Lima: Maijosa; 1991. 